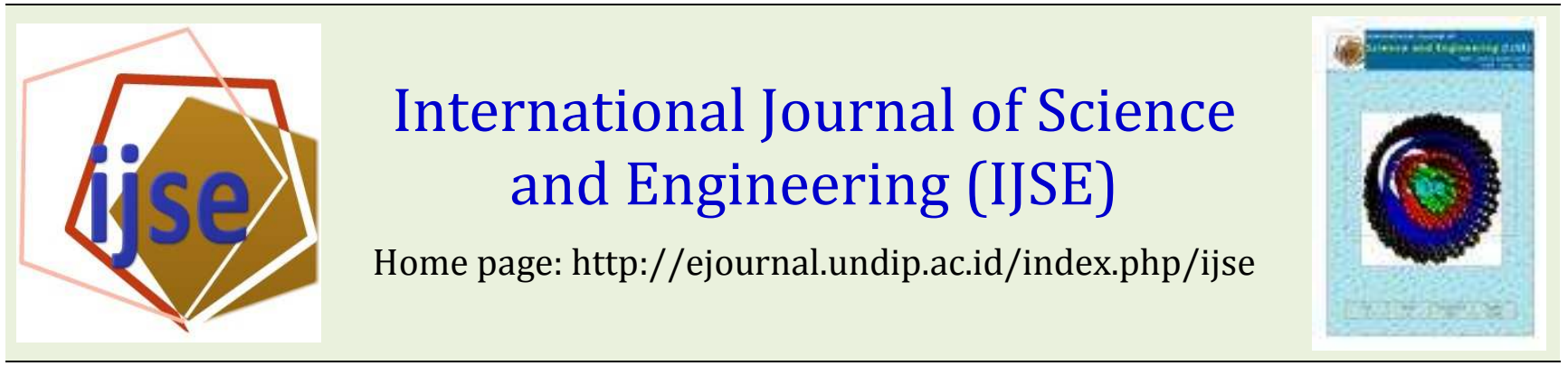

\title{
Reservoir Operation to Minimize Sedimentation
}

\author{
Dyah Ari Wulandari ${ }^{1}$, Djoko Legono ${ }^{2}$, Suseno Darsono ${ }^{1}$ \\ ${ }^{1}$ Civil Engineering Department, Diponegoro University, Semarang, Indonesia. \\ ${ }^{2}$ Civil Engineering Department, Gadjah Mada University, Yogyakarta, Indonesia. \\ Coorresponding Author: dyahariwulandari@yahoo.co.id
}

\begin{abstract}
The Wonogiri Reservoir capacity decreases rapidly, caused by serious sedimentation problems. In 2007, JICA was proposed a sediment storage reservoir with a new spillway for the purpose of sediment flushing / sluicing from The Keduang River. Due to the change of reservoir storage and change of reservoir system, it requires a sustainable reservoir operation technique. This technique is aimed to minimize the deviation between the input and output of sediments. The main objective of this study is to explore the optimal Wonogiri reservoir operation by minimizing the sediment trap. The CSUDP incremental dynamic programming procedure is used for the model optimization. This new operating rules will also simulate a five years operation period, to show the effect of the implemented techniques. The result of the study are the newly developed reservoir operation system has many advantages when compared to the actual operation system and the disadvantage of this developed system is that the use is mainly designed for a wet hydrologic year, since its performance for the water supply is lower than the actual reservoir operations.
\end{abstract}

Keywords - Reservoir Operation, Sediment Control, Wonogiri Reservoir, Mathematic Model

Submission: 1 Juny 2013

Corrected : 24 October 2013

Accepted: 26 October 2013

Doi: $10.12777 /$ ijse.6.1.16-23

[How to cite this article: Wulandari, D.A., Legono, D., and Darsono, S., 2014. Reservoir Operation to Minimize Sedimentation. International Journal of Science and Engineering, 5(2),61-65. Doi: 10.12777/ijse.6.1.16-23]

\section{INTRODUCTION}

In many practical situations, operating rules are established at the planning stage of the proposed reservoir, and these rules will provide guidelines for reservoir releases to meet planned demands. After reservoir operate a few years, important presumably to evaluate and renew operating patterns, to adjust to change the existing. Improvement system of the operation of this may be caused due to the following reasons (1) change in demands (2) change in hydrology and (3) change in reservoir storage. Therefore, adequate reservoir operations information could provide insight for reevaluating the system-wide water resources planning and management for planning purposes (Tu et al. 2003, Tu et al. 2008 and Wulandari et al. 2012). The evaluations of the storage-yield and the operational performance of a reservoir form an important part in the study of water resources development. Application of the mode, ling for reservoir system analysis involves studies especially to reevaluate storage-yield and operation performance for existing reservoir systems. Such periodic evaluation may be required to assess the responsiveness of a system to prevailing conditions and demands arising out of ever changing water use patterns (Srivastava,
2009). Research on the reservoir operation in relation to control reservoir sedimentation have done by some researchers, as follows Nicklow \& Mays (2000), Chang et al. (2003), Ji (2006) and Hadihardaja (2009). The research show due to sedimentation problems in reservoir, it becomes necessary to develop reservoir operation for control sediment and the operation produce the performance of good.

The Wonogiri Reservoir is a multipurpose reservoir, located at the Bengawan Solo River in the Wonogiri Regency, Central Java Province of Indonesia. The reservoir copes with the problems of rapid capacity decrease, deposition of sediment in and around the intake and the reduction of effective storage. Sedimentation leads to reduction of the reservoir's economic life, disruption of operations due to intake clogging from The Keduang River debris and a decrease in the water reservation ability, especially during the dry season. Reservoir sedimentation measurements were carried out in 2011 by PJT I and it was found that the remaining of dead storage capacity is only $50 \%$ with a remaining effective storage capacity of only $70 \%$ of the design storage capacity. According to the result of this recent 
study, the Wonogiri reservoir is only able to fulfill $72 \%$ of its water demand.

Based on the results of the JICA study in 2007, a sediment storage reservoir with a new spillway for the purpose of flushing/sluicing the sediments from The Keduang River, was built. This countermeasure is only focused on controlling the sediment inflow from The Keduang River, whereas other tributaries which account for about $60 \%$ are not taken into consideration. It therefor becomes necessary to develop new operating rules, to overcome the aspect not covered by the actual situation. The new operating rules should take into consideration the sediment control by adjusting the reservoir operation, minimizing the difference between inflow and outflow of sediments. The main purpose of this study is the development of an optimization operating rule for minimizing the sediment's trap.

\section{DESCRIPTION OF THE WONOGIRI RESERVOIR}

The reservoir watershed measures $1,305 \mathrm{~km}^{2}$ and is located in the Southeast part of the Central Java province (Figure 1). The location has a mountainous area of situated at the Upper Bengawan Solo river basin. The Wonogiri watershed consists of eight sub-watersheds namely: Keduang (420.95 $\left.\mathrm{km}^{2}\right)$, Tirtomoyo/Wiroko (230.64 km²), Temon/Beling (62.59 km²), Bengawan Solo Hulu (205.52 km²), Alang (169.38 km²), Ngunggahan $\left(82.39 \mathrm{~km}^{2}\right)$, Wuryantoro $\left(44.17 \mathrm{~km}^{2}\right)$ and the Remnant Area $\left(27.67 \mathrm{~km}^{2}\right)$. Annually average rainfall is 1900 $2100 \mathrm{~mm}$ annually. The latitude of the watershed fluctuates between 50 - $150 \mathrm{~m}$ above the sea level.

The reservoir functions for flood control, water supply for industrial and drinking water, irrigation, hydropower, fisheries and tourism and maintenance of the Bengawan Solo River. The storage at the elevation of 135.3 to 138.3 $\mathrm{m}$ is allocated for flood control. Priorities of the reservoir purposes are: irrigation and industrial and drinking water, while the purpose of hydropower is in accordance with the actual discharge. The water storage provided for this purpose is situated at the elevation of 127-136 m, while the dead storage is positioned at an elevation below $127 \mathrm{~m}$.

The outflow from the reservoir goes through the spillway, turbine outlet and hollow jet valve (river outlet). The release through spillway is designed for flood conditions, and the release for water supply through the turbine outlet is conducted to maximize the induced hydropower. If the power plant does not operate and a demand for the water supply occurs, the release is directed through the hollow jet valve. At flooding, the power plants continue to operate. In this case the discharge amount through the turbine outlet and spillway has a maximum of 400 $\mathrm{m}^{3} / \mathrm{sec}$. The turbine does not show any damage due to abrasion since it operation started in the mid-1980s, indicating that only the fine sediments passes through the turbine. It could be well concluded that the turbine is safe from abrasion (JICA, 2007b).

The reservoir intake position for the dead storage easily gets clogged by sediments and trash from the Keduang River. To overcome this issue, a sediment storage reservoir with a new spillway is currently being built. Here the construction is separated into two reservoirs, one for sediment storage purposes and another as main reservoir (Figure 2). The sediment storage reservoir functions to hold the incoming sediment and trash from The Keduang River and for flushing / sluicing the sediments from The Keduang River without lowering the water level in the main reservoir. The sediment storage reservoir is equipped with a spillway gate having a width of $30 \mathrm{~m}$ and crest elevation of $+127.00 \mathrm{~m}$. When the Keduang reservoir water level is between 127-136 m, water use is directed through a conduits, and when the water elevation is above $136 \mathrm{~m}$, the water is guided through the overflow dike.

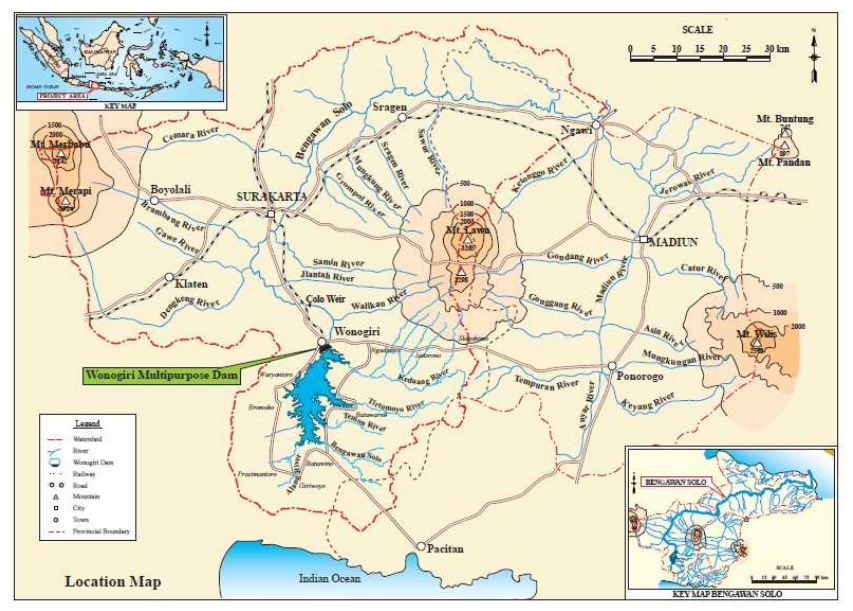

Fig. 1. Map of The Wonogiri Reservoir (JICA, 2007a).

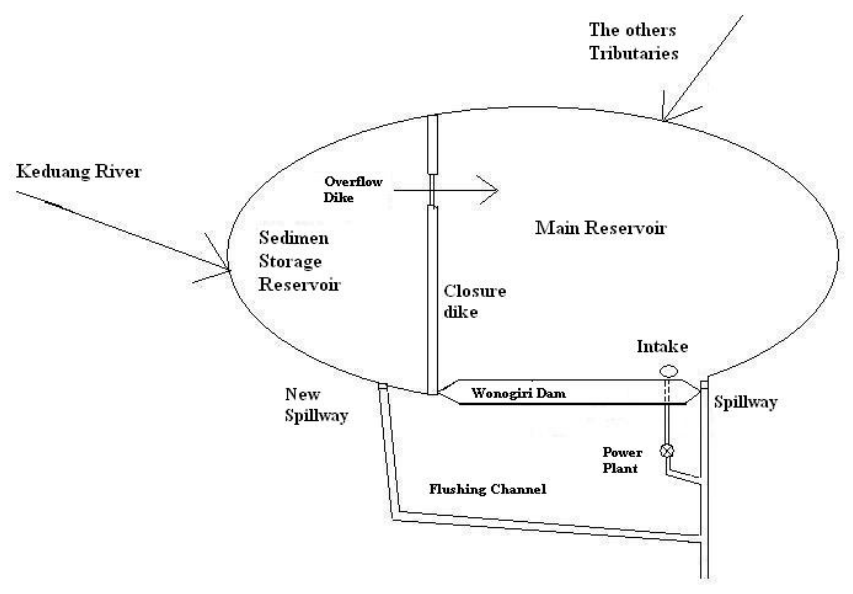

Fig. 2. Sediment storage reservoir sketch.

\section{METHODS}

For this study, first we defined objective function and constraints, and then do the optimization. The result of optimization is new operating rules. The new operating rules then simulated for last five years period, to show the effect and performance of the techniques implemented. Based on actual reservoir operation last 5 years seen its performance, and then compared with the 
simulation results and the new operating rules to be evaluated.

\subsection{Model Formulation}

The model was developed to regulate the release in controlling the sediment as well as to fulfill irrigation needs, industrial and drinking water, and river maintenance purposes. For hydropower purpose, the release is in accordance with the water supply. The water supply elevations for these objectives are elevation at 127 $\mathrm{m}$ to $136 \mathrm{~m}$, and for flood control the elevation is between $135.3 \mathrm{~m}$ to $138.3 \mathrm{~m}$. The reservoir is distinguished into two storage parts, i.e. the Keduang Reservoir and the Wonogiri Reservoir. The Keduang Reservoir and the Wonogiri Reservoir are operated in series (Figure 3). Inflow from the Keduang River is used for the Keduang Reservoir flushing/ sluicing, during the period of February to middle April. Surplus from The Keduang reservoir is spilled out to the Wonogiri reservoir through the conduits or spillway. The Wonogiri Reservoir sediment control is directed through the intake and spillway and is operated during the rainy season (November till April). The average inflow is 1,298 million $\mathrm{m}^{3}$ and the designed water demand is around 600 million $\mathrm{m}^{3}$, resulting in a 600 million $\mathrm{m}^{3}$ water surplus that can be used for sediment flushing (Table 1).
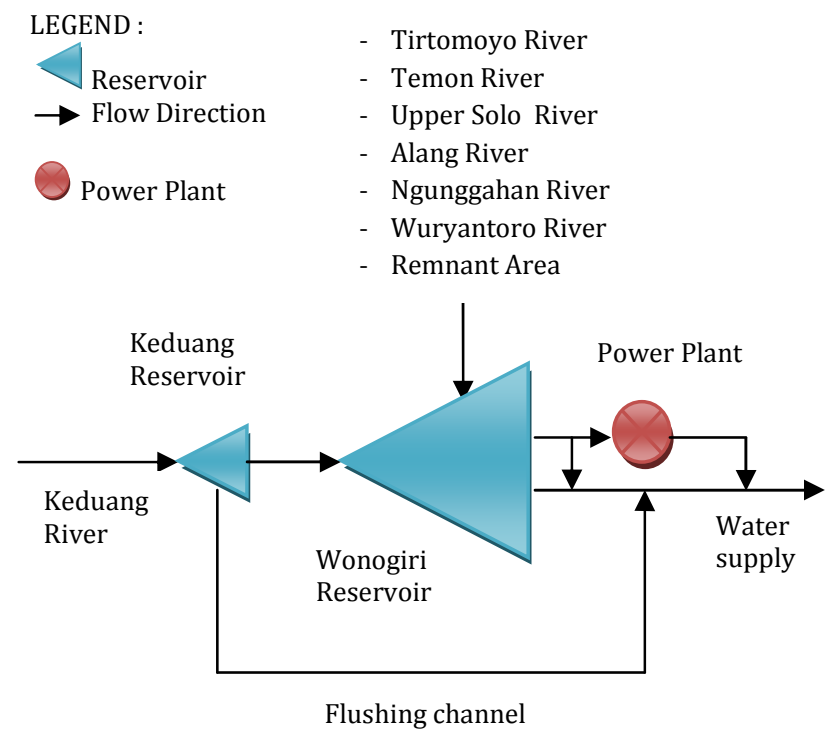

Fig. 3. The reservoir system scheme.

Table 1 : Outflow, inflow and water demand (1983-2012)

\begin{tabular}{l|r}
\hline Description & $\begin{array}{c}\text { Annual Volume } \\
\text { (MMC) }\end{array}$ \\
\hline Average outflow from intake & 913.25 \\
\hline Average outflow from spillway & 228.11 \\
\hline Water demand design & 566.69 \\
\hline Average inflow & $1,298.63$ \\
\hline
\end{tabular}

\subsubsection{Stage, State Variables and Decision Variables}

Stage in this research has a two-week period (within one year, 24 stages exist). The state variable in this study is the initial reservoir storage of the $\mathrm{i}^{\text {th }}$ period. The deciding variable for this study is taken for the release at the $\mathrm{i}^{\text {th }}(\mathrm{Xi})$ period.

\subsubsection{Objective Function}

Optimization objectives in this study are:

- For The Keduang Reservoir: minimization of the difference between sediment inflow and outflow, with the following objective function:

$$
\operatorname{Min} Z=A x \sum_{i=1}^{N}\left|V s i_{1, i}-V s o_{1, i}\right|
$$

(1)

- For The Wonogiri Reservoir: minimization of the trapping sediment by sediment control during the rainy season, having the following objective function:

$$
\operatorname{Min} Z=B x \sum_{i=1}^{N}\left|V s i_{2, i}-V s o_{2, i}\right|+C x \sum_{i=1}^{N} \frac{\left|T_{2, i} X_{2, i}\right|}{T_{2, i}}
$$

If there is sediment control $A=1$ and if there is no sediment control $\mathrm{A}=0$

If there is sediment control $B=1$, and if there is no sediment control $\mathrm{B}=0$

If there is sediment control $\mathrm{C}=0$ and if there is no sediment control $\mathrm{C}=1$

Where:

$\mathrm{Z}$ = objective function

$\mathrm{i}^{\text {th }}=$ stage

$\mathrm{N}=$ number of the period under review

$F_{i}=$ release for Flushing / sluicing of the $i^{\text {th }}$ period

$\mathrm{X}_{\mathrm{i}}=$ release of the $\mathrm{i}^{\text {th }}$ period

$\mathrm{T}_{\mathrm{i}}=$ Target water demand of the $\mathrm{i}^{\text {th }}$ period

$V s i=$ sediment inflow Volume

$V s o=$ sediment outflow Volume

\subsubsection{State Transformation Function}

To express the relationship of the reservoir conditions storage for one period to the next, the reservoir water balanced equation (Nandalal \& Bogardi, 2007) is chosen:

- For The Keduang Reservoir :

$$
S_{1, i}=S_{1, i-1}+I_{1, i}-O_{1, i}-X_{1, i}-O F_{1, i}
$$

If there is flushing/ sluicing $O_{1, i}=0$ dan $X_{1, i}=0$

- For The Wonogiri Reservoir :

$$
S_{2, i}=S_{2, i-1}+I_{2, i}-O_{2, i}+O_{1, i}+X_{1, i}-X_{2, i}-E_{2,(i-1, i)}
$$

Where :

$\mathrm{I}_{\mathrm{j}, \mathrm{i}}=$ total reservoir inflow from tributaries $\mathrm{j}$ of the $\mathrm{i}^{\text {th }}$ period

$\mathrm{S}_{\mathrm{i}, \mathrm{i}}=$ Storage of reservoir $\mathrm{j}$ of the $\mathrm{i}^{\text {th }}$ period

$\mathrm{S}_{\mathrm{j}, \mathrm{i}-1}=$ Storage of reservoir $\mathrm{j}$ of the $(\mathrm{i}-1)^{\text {th }}$ period

$\mathrm{OF}_{\mathrm{j}, \mathrm{i}}=$ release reservoir $\mathrm{j}$ for flushing / sluicing of the $\mathrm{i}^{\text {th }}$ period

$\mathrm{O}_{\mathrm{j}, \mathrm{i}}=$ spill out reservoir $\mathrm{j}$ of the $\mathrm{i}^{\text {th }}$ period

$\mathrm{E}_{\mathrm{j},(\mathrm{i}-1, \mathrm{i})}=$ evaporation in reservoirs $\mathrm{j}$ between the $(\mathrm{i}-1)^{\text {th }}$ and the $\mathrm{i}^{\text {th }}$ period

$\mathrm{X}_{\mathrm{j}, \mathrm{i}}=$ release reservoir $\mathrm{j}$ of the $\mathrm{i}^{\mathrm{t} \text { th }}$ period 


\subsubsection{Constrains}

Constrain is the limitation factor of the storage and

release, as following:

The water storage reservation for the water supply is situated at the elevations of $127 \mathrm{~m}$ to 136 . Base on Capacity-Elevation Curves the storage limitation factor are obtained as follows:

The Keduang Reservoir : $0.17 \leq \mathrm{Si} \leq 14 \mathrm{MMC}$

The Wonogiri Reservoir: $59.3 \leq \mathrm{Si} \leq 350.94 \mathrm{MMC}$

The Keduang Reservoir release is limited by Conduit capacity :

$0 \leq \mathrm{Xi} \leq 12.3 \mathrm{~m}^{3} / \mathrm{s}$

If there is sediment control then $\mathrm{Xi}=0$

The Wonogiri Reservoir release is limited by intake capacity and target as follows:

$$
\begin{aligned}
& 0 \leq \mathrm{Xi} \leq 75 \mathrm{~m}^{3} / \mathrm{s} \\
& \text { In dry season : } \mathrm{Xi} \leq \text { Target }
\end{aligned}
$$

Release and spill out The Keduang Reservoir and The Wonogiri reservoir are limited by maximum river discharge downstream as follows:

$$
\mathrm{OF}_{1, \mathrm{i}}+\mathrm{X}_{2, \mathrm{i}}+\mathrm{O}_{2, \mathrm{i}} \leq 400 \mathrm{~m}^{3} / \mathrm{s}
$$

If inflow $\geq 4.000 \mathrm{~m}^{3} / \mathrm{s}$ then $0 \mathrm{~F}_{1, \mathrm{i}}+\mathrm{X}_{2, \mathrm{i}}+\mathrm{O}_{2, \mathrm{i}} \geq 400 \mathrm{~m}^{3} / \mathrm{s}$

\subsubsection{Recursive equation}

The function between the optimal decision of the $\mathrm{i}^{\text {th }}$ period and the optimal decision of the $(i+1)^{\text {th }}$ period is expressed by the following relationship :

$$
\boldsymbol{F}_{\boldsymbol{i}}\left(\boldsymbol{S}_{\boldsymbol{i}}\right)=\min _{\mathrm{X}_{\mathrm{i}}}\left[\boldsymbol{f}_{\boldsymbol{i}}\left(\boldsymbol{S}_{i}, \boldsymbol{X}_{\boldsymbol{i}}\right)+\boldsymbol{F}_{i+1}\left(\boldsymbol{S}_{i+1}\right)\right]
$$

Where :

$\mathrm{F}_{\mathrm{i}}\left(\mathrm{S}_{\mathrm{i}}\right) \quad=$ minimum value of the objective function until the end of the $\mathrm{i}^{\text {th }}$ period

$\mathrm{f}_{\mathrm{i}}\left(\mathrm{S}_{\mathrm{i}}, \mathrm{X}_{\mathrm{i}}\right)=$ the difference between release and water demand

$\mathrm{F}_{\mathrm{i}+1}\left(\mathrm{~S}_{\mathrm{i}+1}\right)=$ minimum value of the objective function until the end of the $(i+1)^{\text {th }}$ period

\subsection{Input Model}

1. Irrigation Purpose Target

Water demand for irrigation, industrial and drinking water, and river maintenance purposes were calculated for the cropping period of 2008/2009 by the BBWS Bengawan Solo, starting on the first day of November.

\section{Inflow}

Reservoir inflow recording equipment is not available. The discharge inflow data are based on the recorded hourly / daily operation historical reservoir data, during the time span of $1983-2012$

\section{Evaporation}

Based on the daily evaporation rate data between 1990 to November 2012, the monthly day evaporation rate is obtained. The relationship between the surface area and reservoir storage was developed based on capacity measuring from 2011 obtained by the PJT I. Evaporation of the $i^{\text {th }}$ period is calculated with the following equation :

$$
E_{i}=e_{i} x\left[0,00007 x\left(\frac{S_{i}+S_{i+1}}{2}\right)^{2}+0,055 x\left(\frac{S_{i}+S_{i+1}}{2}\right)+0,909\right]
$$

Where :

$E_{i}=$ evaporation

$e_{i}=$ evaporation rate

4. Sediment Inflow and Sediment Outflow

Sediment inflow and outflow discharge are calculated with the equation (13), parameters $a$ and $b$ for each tributary are as shown in Table 2.

$$
Q s=a Q w^{b}
$$

Where:

Qs = suspended sediment discharge

$\mathrm{Qw}=$ water discharge

$\mathrm{a}$ and $\mathrm{b}=$ non linear coefficients

Table 2. Values of a and $b$ for each tributary and outflow

\begin{tabular}{l|r|r}
\hline Tributaries & \multicolumn{1}{l|}{ a } & \multicolumn{1}{l}{ b } \\
\hline Keduang & 0.00027 & 1.601 \\
\hline Tirtomoyo & 0.0004 & 1.477 \\
\hline Temon & 0.00052 & 1.522 \\
\hline Solo & 0.00105 & 1.388 \\
\hline Alang & 0.00037 & 1.628 \\
\hline Ngunggahan & 0.00049 & 1.628 \\
\hline Wuryantoro & 0.00049 & 1.628 \\
\hline Remnant Area & 0.00049 & 1.628 \\
\hline Downstream PLN & 0.00008 & 0.491 \\
\hline Source : JICA 2007b & &
\end{tabular}

For The Keduang Reservoir :

- Sediment inflow : base on inflow from Keduang river

- Sediment outflow : base on spillout from new spillway

For The Wonogiri Reservoir

- If there is sediment control in Keduang Reservoir then sediment inflow : base on inflow from the others tributaries

- If there is no sediment control in Keduang Reservoir then sediment inflow : base on inflow from the others tributaries and outflow from Keduang reservoir

- Sediment outflow : base on release and spillout from Wonogiri reservoir

\section{Discretization}

Discretization is mandated to obtain the decision variables and state variables. A fine discretization will yield in a more accurate result, but a fine discretization also consequences in a longer running iteration process and extensive time.

\section{Incremental Dynamic Programming}

Base on the theory as outlined by Nandalal \& Bogardi (2007), for a multiple-reservoir system it is necessary to obtain an operation policy for all the reservoirs, simultaneously. The main reason is that the optimum condition of the system cannot be investigated by considering reservoirs individually. This requirement, which implies the "curse of dimensionality," prohibits the use of conventional DP for a multiple-reservoir system. 
The IDP technique is considered to be a suitable method to overcome the high dimensional problem. In this technique the reservoir storages and releases are assumed to be the state variables and decision variables, respectively. The IDP procedure begins with the selection of a trial trajectory. A trajectory is the initial value of the objective function (Nandalal \& Bogardi, 2007). For optimization the CSUDP software by Labadie, is chosen (Labadie, 2003).

\subsection{Reservoir Performance}

Operating performance is an indicator of reservoir in operation to meet the needs. Some performance indicators to assess the performance of reservoir operation is the reliability, resilience and vulnerability. Reliability is an indicator of how often the reservoir to meet the needs of the targeted during the operation. Resilience is to measure the ability of the reservoir to return to a satisfactory state of a failed state. If the reservoir back to a satisfactory state faster, it can be said that the reservoir is more resilient so that the consequences of failure smaller. Vulnerability is the magnitude of the failure is obtained from the difference between the capacity of the reservoir and the amount of water needed, divided by the amount of water needed (Suharyanto, 1997).

\section{RESULTS AND DISCUSSION}

After Wonogiri Reservoir operate about 30 years, it is important to evaluate and develop new operating rule, to adjust to the change of reservoir storage and reservoir system. The evaluation is an important part in the study of water resources development (Tu et al. 2003, Tu et al. 2008, Srivastava, 2009 and Wulandari et al. 2012).

To obtain an optimization for the reservoir operation pattern, a new reservoir system, separating the old reservoir system into two reservoirs, namely The Keduang reservoir and The Wonogiri reservoir, is developed. The Wonogiri reservoir and The Keduang Reservoir are distinguished as two reservoirs, operating in series. The optimization is performed by the Incremental Dynamic Programming technique using the CSUDP program package. For the Keduang Reservoir, during the period of February till mid-April, sediment flushing / sluicing is only performed through the spillway (by JICA 2007). As for the Wonogiri reservoir, the optimization is conducted by flushing / sluicing sediment during rainy season. Based on optimization results for sediment flushing / sluicing during the months of November to April, the minimum objective function value was found to be 0.915 . The initial storage was 307.11 million $\mathrm{m}^{3}$ at a water surface elevation of $135 \mathrm{~m}$. The pattern of reservoir operation optimization results can be seen in Figure 6.

Based on the obtained optimal reservoir operation pattern, a simulations over a period of the past five years (years 2007-2012) was performed. This simulation was conducted to determine the effects of sediment control, based on the new operating rules. The graph (Figure 7 Figure 11) shows the storage and release based on the simulation.

The reservoir performance simulation results based on the new operating rule as compared to the actual data, recorded during the operating period of 2007 - 2012 can be seen in Table 3. Based on Table 3 it was found that for the water supply, the actual operation gives a better result when compared to the new operation. As for the purpose of sediment minimization, the new operating rule yields in a higher volume of flushed sediments, suggesting a more efficient water use as compared to the actual reservoir operations. For the flushing $11.31 \mathrm{~m}^{3}$ of sediments, the required water was $1 \mathrm{MMC}$. In terms of flood control, the new operating rule also performs better than the actual operation, because the maximum reservoir water surface elevation is lower than the actual maximum reservoir water surface (Figure 8). This means that a higher leverage for flood control is provided. For fisheries and recreation, the new reservoir operation gives a better result since the minimum reservoir water level is higher than the actual minimum reservoir water level (Figure 8). For hydropower, the new reservoir operation advances in terms that the actual reservoir water-flow through the intake, is larger (Figure 10 and 11). Accordance with the overall objective functions, the new reservoir operations gives a more sophisticated and efficient result. However, the operation of the new reservoirs should be considered to be performed only in a wet hydrologic year, since its performance for the water supply is lower than the actual reservoir operations.

\section{CONCLUSION}

The newly developed reservoir operation system has many advantages when compared to the actual operation system. The volume of sediments flushed through the reservoir with the same amount of water is larger, thus water use is more effective and efficient. The system also provides a better flood control, while for fishery and recreation, a higher water level is maintained, providing a better environment for these purposes. A larger water-flow through the intake reserves a benefit for hydropower target. The disadvantage of this developed system is that the use is mainly designed for a wet hydrologic year, since its performance for the water supply is lower than the actual reservoir operations.

\section{ACKNOWLEDGMENT}

This study is part of Doctoral Higher Education research grant in 2013. Thanks to Higher Education for funding this research. 


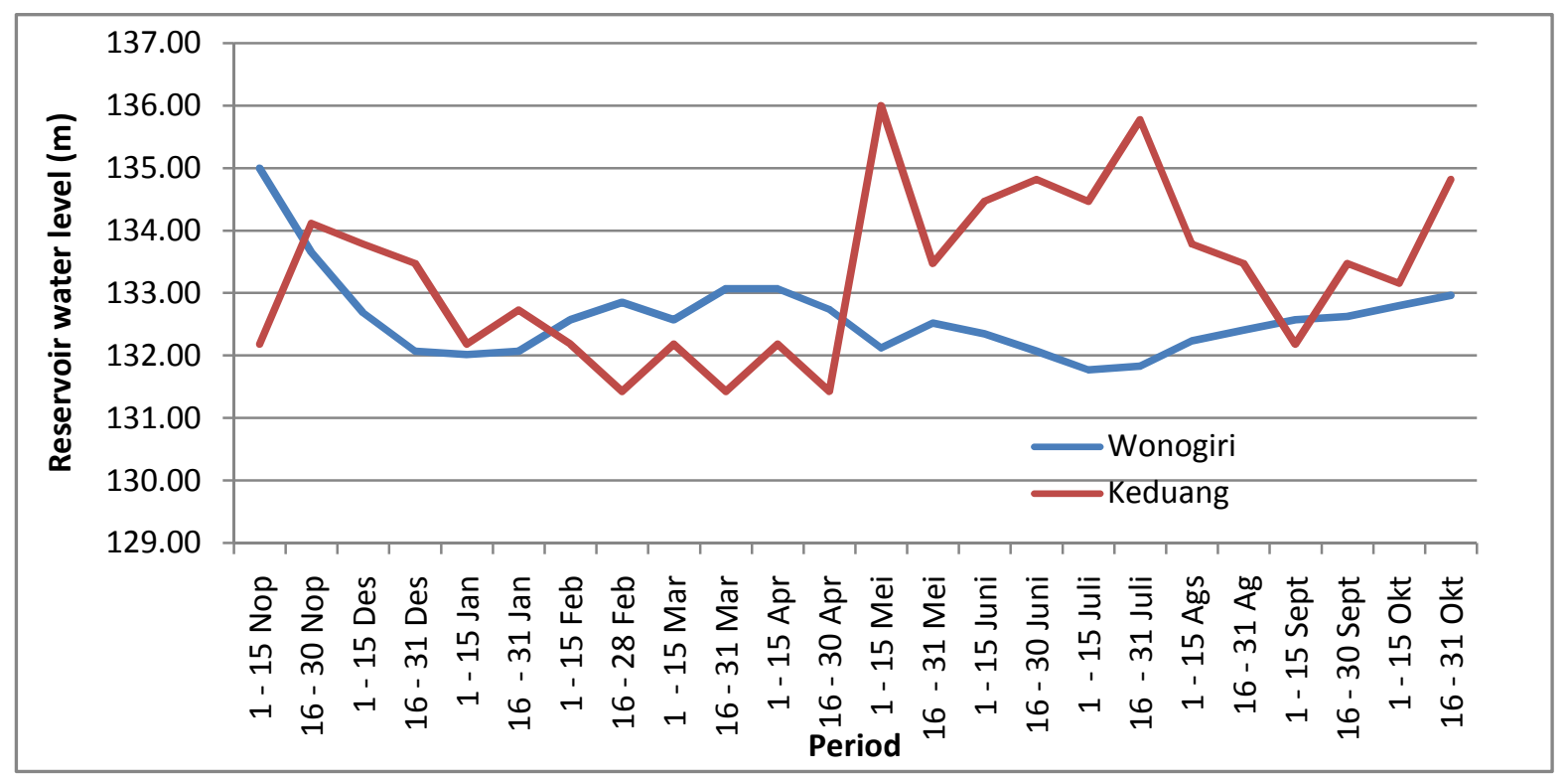

Fig. 6. Rule curve based on Optimation

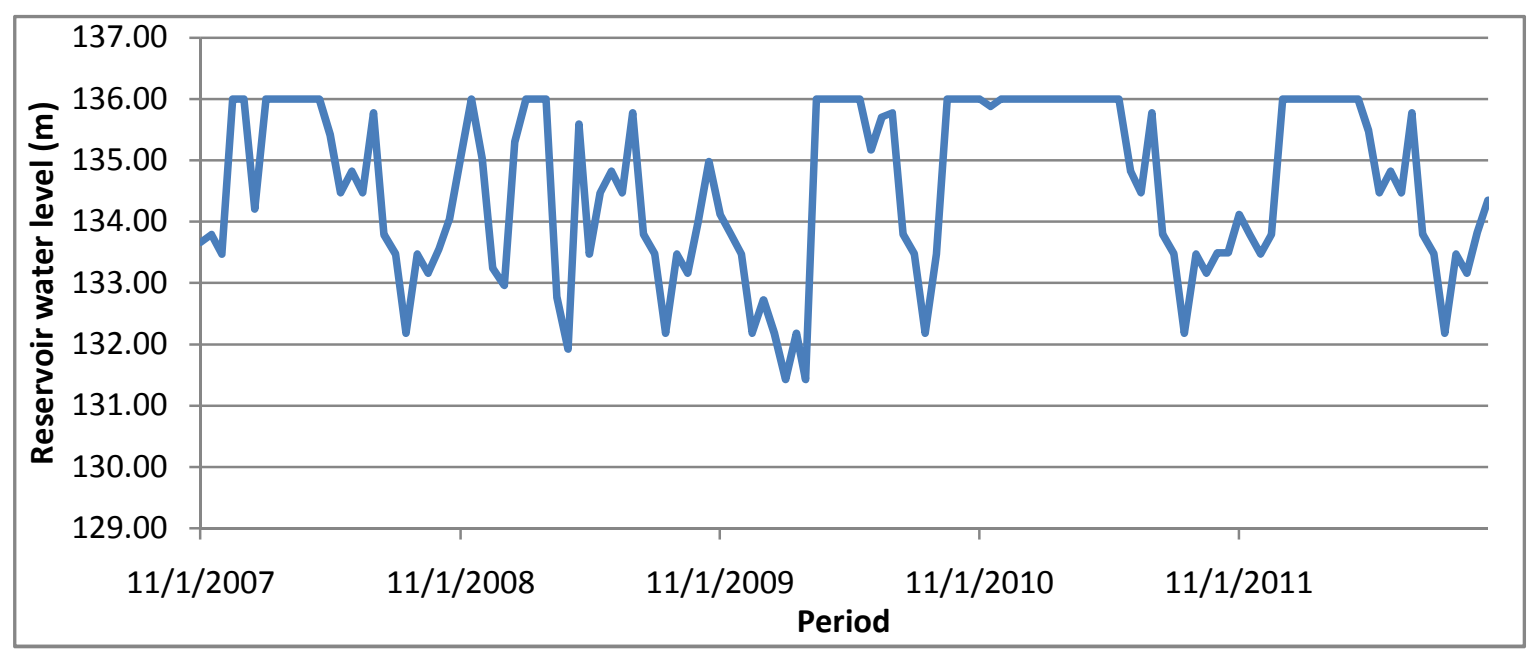

Fig. 7. Storage The Keduang Reservoir, period November 2007 - October 2012

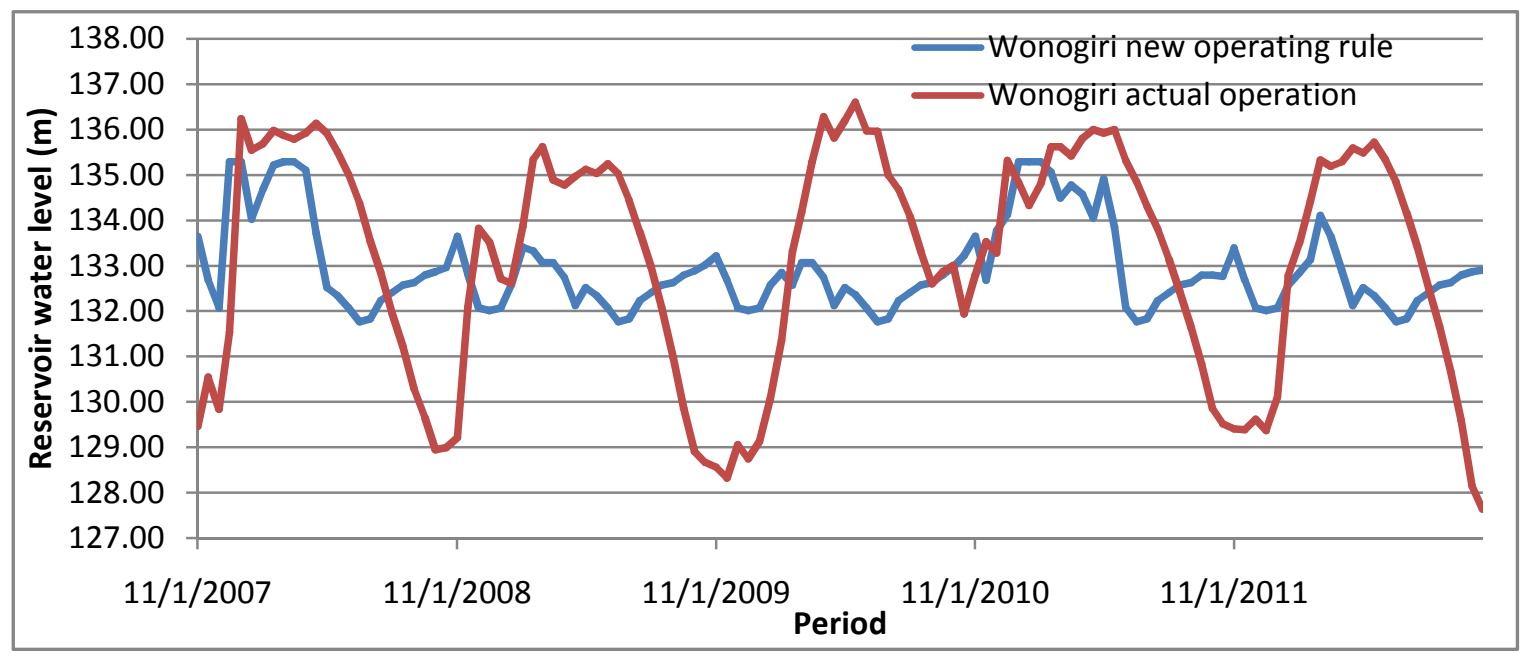

Fig. 8. Storage The Wonogiri Reservoir, period November 2007 - October 2012 


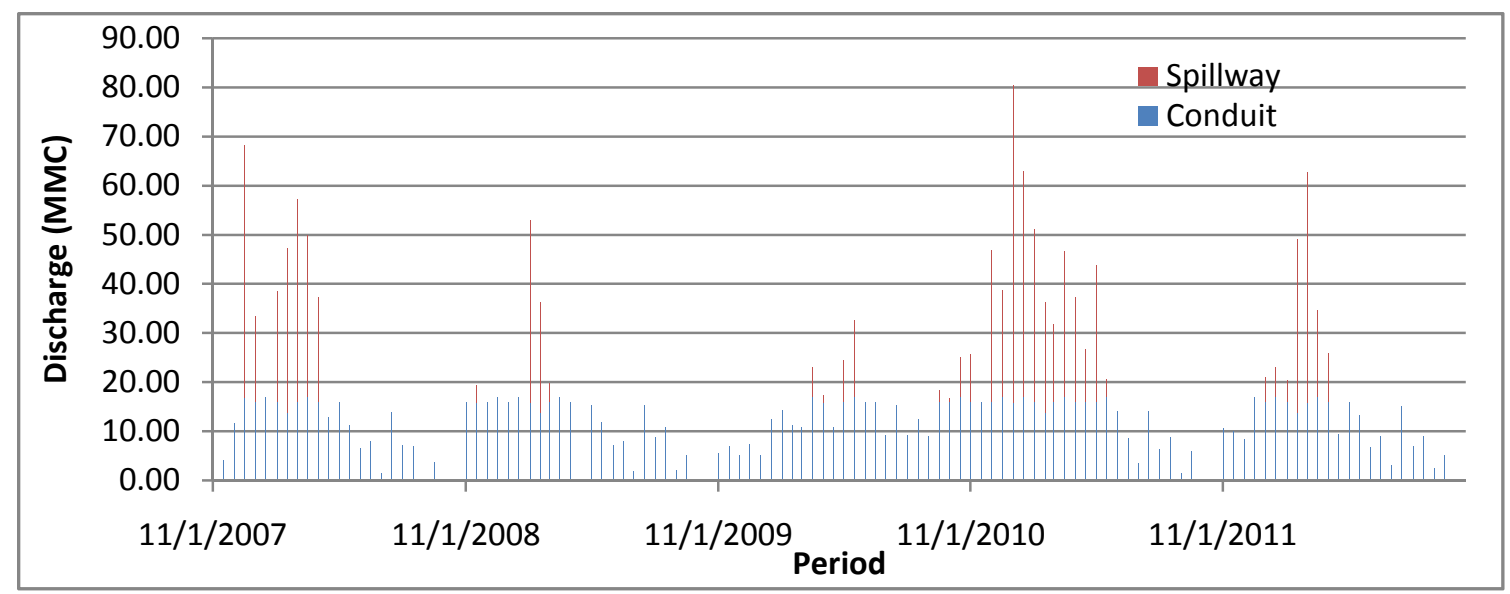

Fig. 9. Outflow from The Keduang Reservoir period November 2007 - October 2012

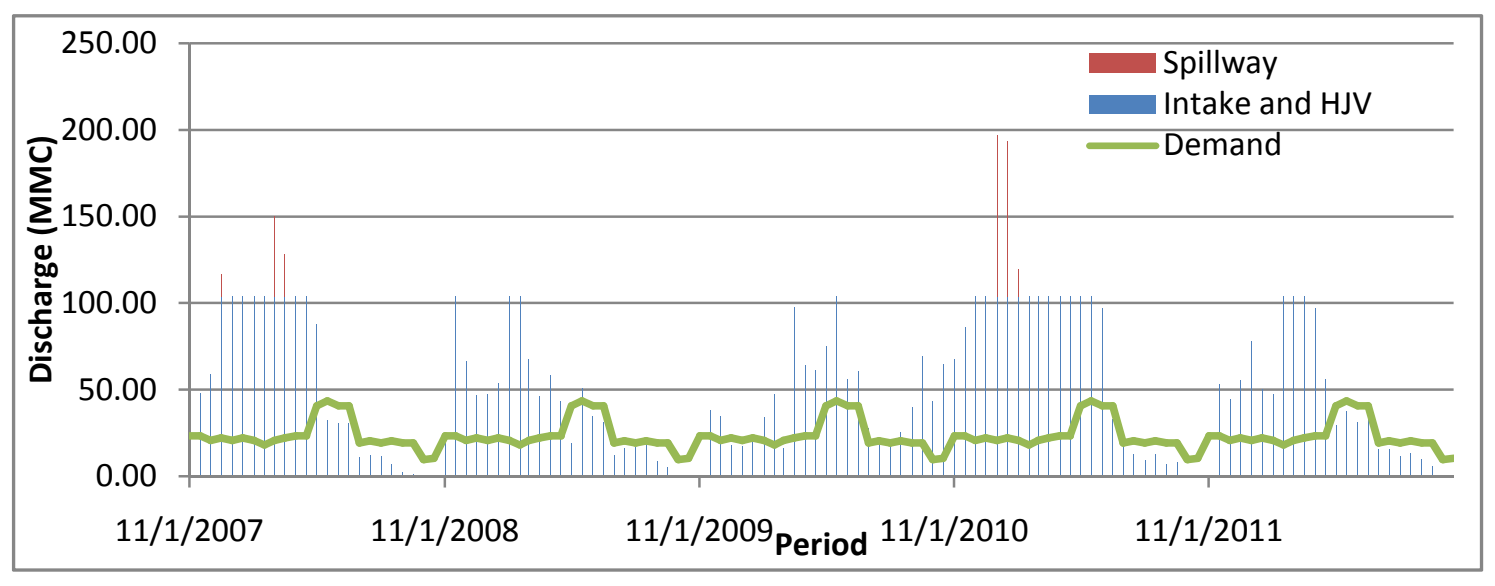

Fig. 10. Outflow from The Wonogiri Reservoir new operating rule in period November 2007 - October 2012

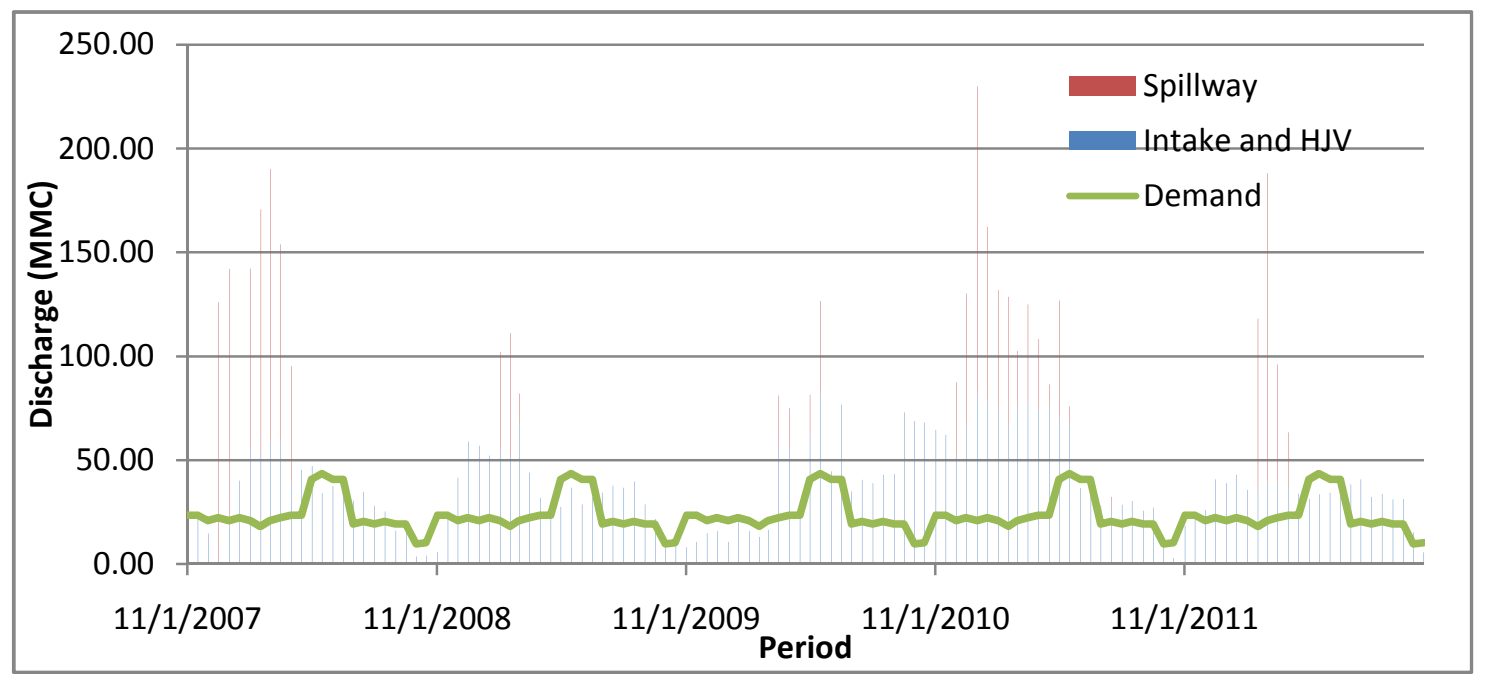

Fig. 11. Outflow from The Wonogiri Reservoir actual operation in period November 2007 - October 2012 
Table 3 Reservoir Performance

\begin{tabular}{l|c|c}
\hline \multirow{2}{*}{ Description } & \multicolumn{2}{c}{ Operation } \\
\cline { 2 - 3 } & $\begin{array}{c}\text { New operating } \\
\text { rule }\end{array}$ & Actual \\
\hline For Irrigation, Industrial \& drinking water, maintenance Solo river \\
\hline Reliability & 0.57 & 0.66 \\
\hline Resiliency & 0.13 & 0.22 \\
\hline Vulnerability & \multicolumn{2}{c}{} \\
\hline - Average deficit ratio & 3.45 & 2.09 \\
\hline - Maximum deficit ratio & 1.00 & 1.00 \\
\hline - Maximum deficit & 23.46 & 22.75 \\
\hline For Minimizing Sediment & 75833.60 & 71633.12 \\
\hline Volume sediment Flushed out (m3) & 6704.54 & 6448.77 \\
\hline Outflow (MMC) & 11.31 & 11.11 \\
\hline efficiency & \multicolumn{2}{|c}{} \\
\hline For Flood Control, Fisheries and tourism & 135.29 & 136.61 \\
\hline Max Reservoir water level (m) & 131.77 & 127.64 \\
\hline Min reservoir water level (m) & 5959.60 & 4414.96 \\
\hline For Hydropower & & \\
\hline Outflow from intake (MMC) & \multicolumn{2}{c}{} \\
\hline
\end{tabular}

\section{ABBREVIATION}

BBWS = Balai Besar Wilayah Sungai (River Basin Office)

JICA = Japan International Cooperation Agency

PJT I =Perum Jasa Tirta I (Public Water Service Corporation)

\section{REFERENCES}

[1] Chang, Fi John; Lai, Jihn Sung \& Kao, Li Shan, 2003. "Optimization of Operation Rule Curve and Flushing Schedule In A Reservoir".. Hydrological Processes, Volume 17, Issue 8, pp. 1623-1640

[2] Hadihardaja, Iwan K., 2009. "Decision Support System for Optimal Reservoir Operation Modeling Within Sediment Deposition Control". Water Science \& Technology, 59.3, pp. 479-489

[3] Ji, Un, 2006. Numerical Model For Sediment Flushing At The Nakdong River Estuary Barrage. PhD Dissertation, Departement of Civil Engineering, Colorado State University, Fort Collins, Colorado, USA , xviii+195p

[4] JICA, 2007a. Volume II : Main Report The Study On Countermeasures For Sedimentation in The Wonogiri Multipurpose Dam Reservoir In The Republic Of Indonesia, Dirjen SDA Kementerian Pekerjaan Umum

[5] JICA, 2007b. Volume III : Supporting Report I The Study On Countermeasures For Sedimentation in The Wonogiri Multipurpose Dam Reservoir In The Republic of Indonesia, Dirjen SDA Kementerian Pekerjaan Umum
[6] Labadie, John W., 2003. User Guide Generalized Dynamic Programming Package CSUDP, Colorado State University, iv+87p

[7] McMahon, Thomas A,; and Russel G. Mein, 1978. Reservoir Capacity and Yield, Elsevier Scientific Publishing Company, Amsterdam, pp. 171-180

[8] Nandalal, K.D.W. and Bogardi, J.J., 2007. Dynamic Programming Based Operation of Reservoir : Applicability and Limits. Cambridge University Press, New York, pp. 16-30

[9] Nicklow., J.W., and Mays, L.W., 2000. "Optimization of Multiple Reservoir Network for Sedimentation Control." Journal of hydraulic Engineering, vol. 126, No. 4, pp. 232-242.

[10] Srivastava, D.K. and Taymoor A. Awchi, 2009. Storage Yield Evaluation and Operation of Mula Reservoir, India, Journal of Water Resources Planning and Management, Vol. 135, No. 6, pp. 414-425

[11] Suharyanto. 1997. Analisa Unjuk Kerja Waduk, Media Komunikasi Teknik Sipil, Edisi VIII, pp. 51-57.

[12] Tu, Ming-Yen; Nien-Sheng Hsu; and William W.-G. Yeh, Hon, 2003. Optimization of Reservoir Management and Operation with Hedging Rules, Journal of Water Resources Planning and Management, Vol. 129, No. 2, pp. 86-97.

[13] Tu, Ming-Yen; Nien-Sheng Hsu; Frank T.-C. Tsai; and William W.-G. Yeh, Hon, 2008. Optimization of Hedging Rules for Reservoir Operation, Journal of Water Resources Planning and Management, Vol. 134, No. 1, pp.3-13.

[14] Wulandari, D.A., Darsono, S., and Legono, D., (2012). Optimasi Pemanfaatan Air Waduk Wonogiri Dengan Program Dinamik, Proceeding PIT HATHI XXIX, Bandung . 